\title{
Effects of spray-drying conditions on the chemical, physical, and sensory properties of cheese powder
}

\author{
Nurcan Koca, ${ }^{* 1}$ Zafer Erbay, $†$ and Figen Kaymak-Ertekin* \\ ${ }^{*}$ Department of Food Engineering, Faculty of Engineering, Ege University, 35100 Izmir, Turkey \\ †Department of Food Engineering, Faculty of Engineering and Natural Sciences, Adana Science and Technology University, 01180 Adana, Turkey
}

\begin{abstract}
Dairy powders are produced to increase the shelf life of fresh dairy products and for use as flavoring agents. In this study, 24 cheese powders produced under 7 different conditions were used to investigate the effects of spray-drying parameters (e.g., inlet air temperature, atomization pressure, and outlet air temperature) on the quality of white cheese powder. Composition, color, physical properties, reconstitution, and sensory characteristics of white cheese powders were determined. The results revealed that the white cheese powders produced in this study had low moisture content ratios and water activity values. High outlet air temperatures caused browning and enhanced Maillard reactions. Additionally, high outlet air temperatures increased wettability and dispersibility and decreased the solubility of white cheese powders. Free fat content was positively correlated with inlet air temperature and negatively correlated with outlet air temperature and atomization pressure. Sensory analyses revealed that white cheese powder samples had acceptable sensory characteristics with the exception of the sample produced at an outlet air temperature of $100^{\circ} \mathrm{C}$, which had high scores for scorched flavor and color and low scores for cheese flavor.
\end{abstract}

Key words: spray drying, cheese powder, white cheese, powder characteristics

\section{INTRODUCTION}

Cheese is one of the most important dairy products with more than 1,000 different varieties (Fox, 2011). Dehydrated cheese (e.g., cheese powder) is usually used as a food ingredient to improve both the flavor and mouthfeel of food products (Fox et al., 2000; Guinee and Kilcawley, 2004; Guinee, 2011). Cheese powder is a promising product with increasing consumption worldwide (Guinee, 2011).

Received November 15, 2014

Accepted February 6, 2015.

${ }^{1}$ Corresponding author: nurcan.koca@ege.edu.tr
Several parameters are used to evaluate cheese powder quality. The composition of cheese powder provides useful information on its physical, structural, and morphological features (Kim et al., 2002; Fitzpatrick et al., 2004; Thomas et al., 2004; Barbosa-Canovas et al., 2005; Paterson et al., 2007; Vignolles et al., 2007). Free fat directly affects oxidation during storage and reconstitution of powders (Kelly et al., 2002; Kim et al., 2002, 2009a; Vignolles et al., 2007, 2009; Park et al., 2014). In addition, distribution of fat plays a role in flavor development and stability, because lipid oxidation is responsible for off-flavor formation and reduced shelf life (Park and Drake, 2014). Physical properties of cheese powders (e.g., color and density) are important parameters of quality; color indicates any defects during processing and storage. Although bulk and tapped densities of powders are used to assess storage, processing, packaging, and distribution conditions, particle density in tandem with bulk and tapped densities provide valuable information on particle properties and interactions (Barbosa-Canovas et al., 2005; Schuck, 2011). Factors that negatively affect flavor, color, or texture during processing and storage are of concern. Nonenzymatic browning (i.e., the Maillard reaction) is one of the main factors that cause the formation of chemically stable and nutritionally unavailable derivatives from dairy powders (Palombo et al., 1984; Kilic et al., 1997). Furthermore, most food additives prepared in powder form are hydrated before use. Therefore, interfacial properties, water interactions, and dissolution of dairy powders are important factors in food development and formulation (Thomas et al., 2004; Schuck, 2011; Richard et al., 2013). The reconstitution of dairy powders with water depends on several properties such as their wettability, sinkability, dispersibility, and solubility (Freudig et al., 1999; Schuck, 2011). In addition, sensory characteristics are important to achieve customer satisfaction.

Cheese powder production involves 4 main steps. First, the blend formulation is determined. The blend consists mainly of natural cheese, water, emulsifying salts, and different additives such as dairy ingredients (skim milk solids, whey, and lactose), starch, maltodex- 
trins, flavors, and flavor enhancers (enzyme-modified dairy ingredients, $\mathrm{NaCl}$, monosodium glutamate, yeast extracts), antioxidants, and, sometimes, coloring agents. Second, the blend is heated to 75 to $85^{\circ} \mathrm{C}$ and sheared, resulting in a hot molten slurry. Third, homogenization may be performed at 15 and $5 \mathrm{MPa}$. Finally, the hot molten slurry is spray dried. In the production of cheese powder, the most important process is spray drying (Fox et al., 2000; Guinee and Kilcawley, 2004; Guinee, 2011; Varming et al., 2013).

Spray drying is a suspended-particle processing technique that has become the most important method for drying fluid foods (Filkova et al., 2006). The main food sector that uses spray driers is the dairy industry (Bhandari et al., 2008). The properties of dairy powders and the costs of dairy powder production are affected by the spray-drying process (Schuck, 2002; Vignolles et al., 2009; Erbay and Koca, 2012a).

Even though there is increasing demand for dairy powders and cheese powders, cheese powders are rarely described in the scientific literature (Kilic et al., 1997; Srinivasan et al., 2000; Varming et al., 2010, 2013; Erbay and Koca, 2015). One study focused on the effects of spray drying on the volatile compounds in cheese powder (Varming et al., 2011). The current study investigated the effects of spray drying on cheese powder quality.

\section{MATERIALS AND METHODS}

\section{Materials}

White cheese (previously ripened for 7 mo) was supplied by Sütaş Dairy Company (Bursa, Turkey). Water, fat, protein, ash, and salt contents of white cheese were $52.0,24.4,18.4,4.9$, and $4.3 \%$, respectively. White cheese blocks were ground into small pieces, which were transferred to air- and water-tight durable polypropylene plastic containers, stored at $2^{\circ} \mathrm{C}$, and processed within $48 \mathrm{~h}$.

Before spray drying, a white cheese slurry consisting of ground white cheese, water, and $3 \%$ Joha emulsifying salts (Kipa Chemical Company, Istanbul, Turkey) was prepared. The slurry was heated by adding water at $80^{\circ} \mathrm{C}$ and sheared in a blender (model LB10S, Waring, Torrington, CT) at 6,000 rpm for $1 \mathrm{~min}$. Subsequently, the slurry was heated in a water bath to $80^{\circ} \mathrm{C}$ and sheared again at 6,000 rpm for $10 \mathrm{~min}$. The slurry $(25 \%$ DM based on cheese) was transferred to a spray drier at $45^{\circ} \mathrm{C}$.

\section{Spray-Drying Procedure}

The white cheese slurry was dried in a pilot-scale spray drier (Mobile Minor Niro-Atomizer, Soeborg,
Denmark). The schematic illustration of the spray drier was shown in a previous study (Erbay and Koca, 2012b). Cheese slurry (3.2 L for each batch) was pumped using a peristaltic pump (BT600-2J, Longer Precision Pump, Baoding, Hebei, China) into a rotary atomizer and atomized into a drying cabinet $(1.2 \mathrm{~m}$ high $\times 0.87 \mathrm{~m}$ in diameter). The feed rate was adjusted based on the inlet and outlet drying air temperatures. The rotary atomizer was controlled by an air turbine wheel at 20,000 to $31,500 \mathrm{rpm}$. The atomizer wheel had a $50-\mathrm{mm}$ diameter with 24 vanes to create a uniform atomization. The co-current airflow was $0.08 \mathrm{~kg} / \mathrm{s}$. Experiments were performed with an inlet air temperature of 160 to $230^{\circ} \mathrm{C}$, an outlet air temperature of 60 to $100^{\circ} \mathrm{C}$, and an atomization pressure of 294 to $588 \mathrm{kPa}$. The cheese powder samples were packaged in polyethylene terephthalate/aluminum/low-density polyethylene (PET/Al/LDPE)and analyzed within $48 \mathrm{~h}$. To prevent cross-contamination between samples, the drying chamber was washed with detergent and hot water and then a run without sample was performed between samples.

\section{White Cheese Powder Composition}

Moisture, fat, and protein contents of white cheese powder samples were determined by gravimetric (IDF, 1982), Gerber (IDF, 1981), and Kjeldahl (AOAC International, 2000; method 991.20) methods, respectively. Ash and salt contents were determined by the gravimetric (AOAC International, 2000; method 930.30) and Mohr (IDF, 1988) methods, respectively. Titratable acidity was expressed as percent lactic acid (AOAC International, 2000; method 947.05); pH was measured with a $\mathrm{pH}$ meter.

\section{Color Evaluation}

Using a Hunter ColorFlex colorimeter (Hunter Associates Laboratory, Reston, VA), white cheese powder color was measured in terms of $\boldsymbol{L}$ (lightness), $\boldsymbol{a}$ (redness and greenness), and $\boldsymbol{b}$ (yellowness and blueness). A quartz 2.5-inch glass containing the cheese powder was placed above the light source and covered with an opaque cover. Then, $L, a$, and $b$ values were recorded. Color differences $(\boldsymbol{\Delta} \boldsymbol{E})$, chroma (color intensity), and browning index (BI) values were calculated as described previously (Askari et al., 2008):

$$
\Delta E=\sqrt{\left(L_{0}-L\right)^{2}+\left(a_{0}-a\right)^{2}+\left(b_{0}-b\right)^{2}},
$$

$$
\text { Chroma }=\sqrt{a^{2}+b^{2}} \text {, and }
$$




$$
\mathrm{BI}=\frac{100 \times\left[\frac{(a+1.75 \times L)}{(5.645 \times L+a-3.012 \times b)}\right]}{0.17} .
$$

\section{Nonenzymatic Browning}

The nonenzymatic browning degrees (NBD) of white cheese powder samples were measured by an enzymatic digestion method (Palombo et al., 1984; Kilic et al., 1997). The method was based on pronase proteolysis, which releases brown pigments. In this experiment, $1 \mathrm{~g}$ of white cheese powder was used. Sample absorbance was measured at $420\left(\mathrm{~A}_{420}\right)$ and $550\left(\mathrm{~A}_{550}\right) \mathrm{nm}$ in a spectrophotometer (Cary 50 Bio UV-Visible Spectrophotometer, Varian, Palo Alto, CA). Optical density was calculated using the following equation:

$$
\mathrm{OD}=\mathrm{A}_{420}-\mathrm{A}_{550}
$$

and the NBD values for each sample were expressed as $\mathrm{OD} / \mathrm{g}$ of $\mathrm{DM}$.

\section{Powder Density Determination}

Bulk, tapped, and particle densities of white cheese powders were measured. Bulk density was measured by pouring white cheese powder to the $100-\mathrm{mL}$ mark of a tared graduated cylinder and recording the weight (Jinapong et al., 2008). The measuring cylinder was tapped 200 times, and the volume was recorded to calculate the tapped density (Jinapong et al., 2008). Particle density was measured by the fluid displacement method in a $100-\mathrm{mL}$ volume liquid pyknometer and with petroleum ether (Svarovsky, 1987; BarbosaCanovas et al., 2005). All densities were expressed in kilograms per meter cubed.

\section{Powder Reconstitution}

Three properties of white cheese powder (wettability, dispersibility, solubility) were investigated to evaluate the overall reconstitution skills. Wettability was determined by the method described in GEA Niro (2005a) with some modifications. Briefly, $0.075 \mathrm{~g}$ of white cheese powder was added to $100 \mathrm{~mL}$ of distilled water at $35^{\circ} \mathrm{C}$ from a constant height, and the wetting time of the powder particles was observed. Dispersibility was determined by the method described by Jinapong et al. (2008), except that the sieve had a diameter of $500 \mu \mathrm{m}$. Dissolubility was determined as the solubility index by Haenni method (Hawthorne, 1944; Erbay and Koca, 2015).

\section{Free Fat Content}

The free fat content of dairy powders is commonly quantified by the solvent extraction method (Vignolles et al., 2007). In this study, the modified solvent extraction method described in GEA Niro (2005b) was used. The results were expressed as percentage of free fat content.

\section{Scanning Electron Microscopy}

Cheese powder samples were attached to the doublesided adhesive carbon tabs mounted on scanning electron microscopy stubs, coated with gold, and examined under a Philips scanning electron microscope (Philips XL30, Eindhoven, the Netherlands) equipped with a back-scattered electron detector.

\section{Water Activity}

Water activity values of white cheese powder samples were measured with a water activity measurement probe (Testo, Freiburg, Germany).

\section{Sensory Evaluation}

The sensory properties of white cheese powder samples were determined using 10 trained panelists. Caking degree, color (browning degree), scorched flavor, foreign flavor, and cheese flavor were determined. A unipolar scale ranging from 1 (representing to none/ absent) to 9 (representing to highest intensity) was used for each sensory property. To evaluate caking degree, color (browning degree), and scorched flavor, all panelists tried cheese powder samples cooked to different degrees. For cheese flavor, ripened white cheese was used as reference.

\section{Experimental Design and Statistical Analyses}

The experimental design, drying conditions, and production codes are shown in Table 1. The experiments were carried out at different inlet air temperatures $\left(160,195\right.$, and $\left.230^{\circ} \mathrm{C}\right)$, outlet air temperatures $(60,80$, and $100^{\circ} \mathrm{C}$ ), and atomization pressures $(294,441$, and $588 \mathrm{kPa}$ ). Two drying parameters were kept constant while the other parameter was changed. When the inlet and outlet drying air temperatures were 195 and $80^{\circ} \mathrm{C}$ (at the center), respectively, runs were carried out at atomization pressures of 294, 441, and $588 \mathrm{kPa}$. Similarly, when the atomization pressure and outlet drying air temperature were $441 \mathrm{kPa}$ and $80^{\circ} \mathrm{C}$ (at the center), respectively, runs were carried out with inlet drying air temperatures of 160,195 , and $230^{\circ} \mathrm{C}$. When the atomi- 
Table 1. Spray-drying conditions used in the production of white cheese powder

\begin{tabular}{lccc}
\hline Code & $\begin{array}{c}\text { Inlet } \\
\text { temperature } \\
\left({ }^{\circ} \mathrm{C}\right)\end{array}$ & $\begin{array}{c}\text { Atomization } \\
\text { pressure } \\
(\mathrm{kPa})\end{array}$ & $\begin{array}{c}\text { Outlet } \\
\text { temperature } \\
\left({ }^{\circ} \mathrm{C}\right)\end{array}$ \\
\hline 1 & 160 & 441 & 80 \\
2 & 195 & 441 & 80 \\
3 & 230 & 441 & 80 \\
4 & 195 & 441 & 60 \\
5 & 195 & 441 & 100 \\
6 & 195 & 294 & 80 \\
7 & 195 & 588 & 80 \\
\hline
\end{tabular}

zation pressure and inlet drying air temperature were $441 \mathrm{kPa}$ and $195^{\circ} \mathrm{C}$, respectively, runs were carried out with outlet temperatures of 60,80 , and $100^{\circ} \mathrm{C}$.

Six production runs were performed at the second experimental point (center point of drying parameters) and 3 productions performed for all other experimental points (a total of 24 productions were made). The analyses were repeated 3 times. Statistical analyses were performed using SPSS version 13.0 (ver. 13.0 for Windows, SPSS Inc., Chicago, IL). Data were analyzed by ANOVA and Duncan post hoc test. Statistical significance was set at $P<0.05$.

\section{RESULTS AND DISCUSSION}

In this study, we investigated the effects of spray-drying conditions (e.g., inlet and outlet air temperatures and atomization pressure) on properties of white cheese powder. The white cheese powder properties included powder composition (moisture, protein, fat, ash, and salt contents, titratable acidity, and $\mathrm{pH}$ ), color values and nonenzymatic browning ( $L, a, b, \Delta E$, chroma, and NBD), physical properties (bulk, tapped, and particle densities, wettability, dispersibility, solubility index, free fat content, and water activity), and sensory characteristics (sensorial scorched, foreign and cheese flavors, caking, and color).

\section{Effects on Powder Composition}

The average composition of the white cheese powders produced at different spray-drying conditions is shown in Table 2. The average moisture, protein, fat, ash, and salt contents, titratable acidity, and $\mathrm{pH}$ values of cheese powder samples were 1.47 to $2.66 \%, 36.30$ to $36.65 \%$, 46.25 to $46.91 \%, 14.50$ to $14.73 \%, 8.08$ to $8.30 \%, 4.03$ to $4.32 \%$, and 5.41 to 5.57 , respectively. We detected no significant differences in powder composition among the different spray-drying conditions. However, high outlet air temperatures contributed to a reduction in moisture ratio; this effect had no significant value because all moisture content values were $<3 \%$.

\section{Effects on Color Values and Nonenzymatic Browning}

The color values $(L, a$, and $b)$ of white cheese powder samples were measured to calculate $\Delta E$, chroma, and BI. The color values of white cheese slurry and white cheese were used as references during the calculation of 2 different $\Delta E$ values. Moreover, nonenzymatic browning of white cheese powder samples was analyzed (Table 3 ). Inlet air temperature had no significant effect on white cheese powder color. However, atomization pressure increased color values. Additionally, outlet air temperature had dramatic effects on all color values. Although the color values fluctuated at outlet air temperatures of 60 to $80^{\circ} \mathrm{C}$, a significant effect was obtained at $100^{\circ} \mathrm{C}$. The increase in outlet air temperature increased $a, b$, $\Delta E$ (white cheese as reference), chroma, BI, and NBD $(P<0.05)$ and decreased $L$ and $\Delta E$ (white cheese slurry used as reference). These results revealed that lightness decreased whereas redness and yellowness increased with increasing outlet air temperatures. This is a characteristic feature of browning, which was detected in both evaluation of nonenzymatic browning (Table 3) and sensory analyses. The Maillard reaction is induced by temperature, which is mostly attributed to the outlet air temperature in spray-drying processes. The thermal effects could be clearly observed at high outlet air temperatures, in accordance with other published reports (Hardy et al., 1999; Thomas et al., 2004).

The $\Delta E$ values calculated with different reference samples differed based on the spray-drying conditions. Those calculated using white cheese slurry as reference increased as the outlet air temperature increased; however, those calculated using white cheese as reference decreased with increasing outlet air temperatures. Moreover, the color of white cheese powder was similar to that of the white cheese slurry, which is whiter than white cheese. This color variation resulted from the processed cheese production step. The yellow color (b) of a food product is associated with its fat content and the size of fat globules dispersed in the solution or protein matrix. The smaller the fat globule size, the greater the effect of light scattering and the whiter the product. Homogenization of fat increases with the addition of emulsifying salts (McClements, 2005; Cunha and Viotto, 2010).

\section{Effects on Physical Properties}

Outlet air temperature had the greatest effect on the physical characteristics of white cheese powders (Table 4). Inlet and outlet air temperatures caused significant variations on bulk, tapped, and particle densities of the powders. White cheese powders produced at low inlet or outlet air temperatures had higher bulk, tapped, 
Table 2. Variation in product composition with process conditions of spray drying (means \pm SD)

\begin{tabular}{|c|c|c|c|}
\hline \multirow[b]{2}{*}{ Item } & \multicolumn{3}{|c|}{ Inlet temperature } \\
\hline & $160^{\circ} \mathrm{C}$ & $195^{\circ} \mathrm{C}$ & $230^{\circ} \mathrm{C}$ \\
\hline $\begin{array}{l}\text { Moisture content }(\%) \\
\text { Protein }(\%) \\
\text { Fat (\%) } \\
\text { Ash (\%) } \\
\text { Salt (\%) } \\
\text { Titratable acidity (\%) } \\
\text { pH }\end{array}$ & $\begin{aligned} 1.75 & \pm 0.34^{\mathrm{a}} \\
36.65 & \pm 0.17^{\mathrm{a}} \\
46.58 & \pm 0.19^{\mathrm{a}} \\
14.50 & \pm 0.22^{\mathrm{a}} \\
8.21 & \pm 0.11^{\mathrm{a}} \\
4.29 & \pm 0.15^{\mathrm{a}} \\
5.44 & \pm 0.02^{\mathrm{a}}\end{aligned}$ & $\begin{aligned} 1.97 & \pm 0.31^{\mathrm{a}} \\
36.32 & \pm 0.25^{\mathrm{a}} \\
46.69 & \pm 0.00^{\mathrm{a}} \\
14.54 & \pm 0.14^{\mathrm{a}} \\
8.30 & \pm 0.04^{\mathrm{a}} \\
4.15 & \pm 0.28^{\mathrm{a}} \\
5.48 & \pm 0.03^{\mathrm{b}}\end{aligned}$ & $\begin{aligned} 1.56 & \pm 0.19^{\mathrm{a}} \\
36.44 & \pm 0.20^{\mathrm{a}} \\
46.80 & \pm 0.19^{\mathrm{a}} \\
14.52 & \pm 0.28^{\mathrm{a}} \\
8.24 & \pm 0.09^{\mathrm{a}} \\
4.13 & \pm 0.17^{\mathrm{a}} \\
5.52 & \pm 0.02^{\mathrm{b}}\end{aligned}$ \\
\hline \multirow{2}{*}{$\mathrm{pH}$} & \multicolumn{3}{|c|}{ Atomization pressure } \\
\hline & $294 \mathrm{kPa}$ & $441 \mathrm{kPa}$ & $588 \mathrm{kPa}$ \\
\hline \multirow[t]{2}{*}{$\begin{array}{l}\text { Moisture content (\%) } \\
\text { Protein (\%) } \\
\text { Fat (\%) } \\
\text { Ash (\%) } \\
\text { Salt (\%) } \\
\text { Titratable acidity (\%) } \\
\text { pH }\end{array}$} & $\begin{aligned} 1.47 & \pm 0.19^{\mathrm{a}} \\
36.42 & \pm 0.05^{\mathrm{a}} \\
46.69 & \pm 0.00^{\mathrm{a}} \\
14.73 & \pm 0.11^{\mathrm{a}} \\
8.19 & \pm 0.11^{\mathrm{ab}} \\
4.19 & \pm 0.10^{\mathrm{a}} \\
5.47 & \pm 0.02^{\mathrm{b}}\end{aligned}$ & $\begin{aligned} 1.97 & \pm 0.31^{\mathrm{ab}} \\
36.32 & \pm 0.25^{\mathrm{a}} \\
46.69 & \pm 0.00^{\mathrm{a}} \\
14.54 & \pm 0.14^{\mathrm{a}} \\
8.30 & \pm 0.04^{\mathrm{b}} \\
4.15 & \pm 0.28^{\mathrm{a}} \\
5.48 & \pm 0.03^{\mathrm{b}}\end{aligned}$ & $\begin{aligned} 2.33 & \pm 0.40^{\mathrm{b}} \\
36.44 & \pm 0.10^{\mathrm{a}} \\
46.91 & \pm 0.39^{\mathrm{a}} \\
14.60 & \pm 0.18^{\mathrm{a}} \\
8.08 & \pm 0.16^{\mathrm{a}} \\
4.26 & \pm 0.18^{\mathrm{a}} \\
5.41 & \pm 0.04^{\mathrm{a}}\end{aligned}$ \\
\hline & $60^{\circ} \mathrm{C}$ & $80^{\circ} \mathrm{C}$ & $100^{\circ} \mathrm{C}$ \\
\hline $\begin{array}{l}\text { Moisture content (\%) } \\
\text { Protein }(\%) \\
\text { Fat (\%) } \\
\text { Ash (\%) } \\
\text { Salt (\%) } \\
\text { Titratable acidity (\%) } \\
\text { pH }\end{array}$ & $\begin{aligned} 2.66 & \pm 0.08^{\mathrm{a}} \\
36.30 & \pm 0.15^{\mathrm{a}} \\
46.25 & \pm 0.77^{\mathrm{a}} \\
14.66 & \pm 0.01^{\mathrm{a}} \\
8.26 & \pm 0.07^{\mathrm{a}} \\
4.03 & \pm 0.12^{\mathrm{a}} \\
5.57 & \pm 0.08^{\mathrm{b}}\end{aligned}$ & $\begin{aligned} 1.97 & \pm 0.31^{\mathrm{b}} \\
36.32 & \pm 0.25^{\mathrm{a}} \\
46.69 & \pm 0.00^{\mathrm{a}} \\
14.54 & \pm 0.14^{\mathrm{a}} \\
8.30 & \pm 0.04^{\mathrm{a}} \\
4.15 & \pm 0.28^{\mathrm{a}} \\
5.48 & \pm 0.03^{\mathrm{a}}\end{aligned}$ & $\begin{aligned} 1.73 & \pm 0.18^{\mathrm{c}} \\
36.50 & \pm 0.10^{\mathrm{a}} \\
46.69 & \pm 0.00^{\mathrm{a}} \\
14.63 & \pm 0.14^{\mathrm{a}} \\
8.16 & \pm 0.22^{\mathrm{a}} \\
4.32 & \pm 0.13^{\mathrm{a}} \\
5.50 & \pm 0.03^{\mathrm{ab}}\end{aligned}$ \\
\hline
\end{tabular}

${ }^{\mathrm{a}-\mathrm{c}}$ Means within a row with different superscripts differ $(P<0.05)$.

and particle density values. In general, low outlet air temperatures contribute to uniform drying of droplets, controlled particle shrinkage, and higher density values (Kelly et al., 2002). However, higher inlet air temperatures contribute to the formation of vacuoles and air bubbles, which decrease powder density (Kelly et al., 2002; Farkye, 2006).

The reconstitution properties (wettability, dispersibility, and solubility) of white cheese powders are shown in Table 4. Although wettability and dispersibility of powders are mainly affected by the structure and surface properties of the powder particles, solubility is mainly affected by powder composition, especially its protein structure (Kim et al., 2002; Thomas et al., 2004; Henning et al., 2006; Gaiani et al., 2006; Kim et al., 2009a; Schuck, 2011). Accordingly, higher particle size and lower free fat content promote wettability and dispersibility. It has been reported that as the particle size increases, atomization pressure decreases (Freudig et al., 1999; Kim et al., 2002; Schuck, 2011). Our experimental data showed that low atomization pressure had positive effects on wettability and dispersibility of white cheese powder. Furthermore, the results revealed that powder samples with low free fat content (especially at high outlet air temperatures) had improved wettability and dispersibility, in accordance with other studies (Kim et al., 2002; Gaiani et al., 2006). On the other hand, protein structure modifications; for example, polymerization or denaturation due to thermal processes, Maillard reactions, or oxidation, decrease dairy powder solubility (Stapelfeldt et al., 1997; Thomas et al., 2004; Schuck, 2011). The most important factor that affected the solubility index of white cheese powder was outlet air temperature. Increasing outlet air temperatures decrease the solubility index, as reported by other researchers (Anandharamakrishnan et al., 2007, 2008). The relationship between browning index and physical properties of white cheese powders produced at different outlet air temperatures was clear (Tables 3 and 4). The Maillard reaction may be one of the most important factors affecting the physical properties of cheese powder.

There is little evidence on the effects of spray drying on the free fat content of food products (Vignolles et al., 2007; Park et al., 2014); our results are shown in Table 4. The main factor that affected free fat content was outlet air temperature. Increasing outlet air temperatures caused a significant reduction in free fat content 
Table 3. Variation in color features of cheese powder with process conditions of spray drying (means \pm SD)

\begin{tabular}{|c|c|c|c|}
\hline \multirow[b]{2}{*}{ Item $^{1}$} & \multicolumn{3}{|c|}{ Inlet temperature } \\
\hline & $160^{\circ} \mathrm{C}$ & $195^{\circ} \mathrm{C}$ & $230^{\circ} \mathrm{C}$ \\
\hline $\begin{array}{l}L \\
a \\
b \\
\Delta E \text { : slurry } \\
\Delta E \text { : cheese } \\
\text { Chroma } \\
\text { Browning index } \\
\text { Nonenzymatic browning }(\mathrm{OD} / \mathrm{g} \text { of } \mathrm{DM})\end{array}$ & $\begin{aligned} 94.67 & \pm 0.23^{\mathrm{a}} \\
-0.27 & \pm 0.05^{\mathrm{a}} \\
12.51 & \pm 0.77^{\mathrm{a}} \\
3.30 & \pm 0.22^{\mathrm{a}} \\
10.94 & \pm 1.93^{\mathrm{a}} \\
12.51 & \pm 0.77^{\mathrm{a}} \\
13.62 & \pm 0.95^{\mathrm{a}} \\
0.127 & \pm 0.002^{\mathrm{ab}}\end{aligned}$ & $\begin{aligned} 94.62 & \pm 0.34^{\mathrm{a}} \\
-0.24 & \pm 0.11^{\mathrm{a}} \\
12.70 & \pm 0.61^{\mathrm{a}} \\
3.30 & \pm 0.52^{\mathrm{a}} \\
10.42 & \pm 1.30^{\mathrm{a}} \\
12.70 & \pm 0.61^{\mathrm{a}} \\
13.89 & \pm 0.82^{\mathrm{a}} \\
0.120 & \pm 0.006^{\mathrm{a}}\end{aligned}$ & $\begin{aligned} 94.42 & \pm 0.36^{\mathrm{a}} \\
-0.15 & \pm 0.06^{\mathrm{a}} \\
12.68 & \pm 0.44^{\mathrm{a}} \\
3.85 & \pm 0.43^{\mathrm{a}} \\
11.31 & \pm 1.54^{\mathrm{a}} \\
12.68 & \pm 0.44^{\mathrm{a}} \\
13.96 & \pm 0.56^{\mathrm{a}} \\
0.133 & \pm 0.005^{\mathrm{b}}\end{aligned}$ \\
\hline \multirow{2}{*}{ Nonenzymatic browning (OD/g of DM) } & \multicolumn{3}{|c|}{ Atomization pressure } \\
\hline & $294 \mathrm{kPa}$ & $441 \mathrm{kPa}$ & $588 \mathrm{kPa}$ \\
\hline $\begin{array}{l}L \\
a \\
b \\
\Delta E: \text { slurry } \\
\Delta E: \text { cheese } \\
\text { Chroma } \\
\text { Browning index } \\
\text { Nonenzymatic browning }(\mathrm{OD} / \mathrm{g} \text { of } \mathrm{DM})\end{array}$ & $\begin{aligned} 94.33 & \pm 0.24^{\mathrm{a}} \\
-0.22 & \pm 0.04^{\mathrm{a}} \\
13.11 & \pm 0.27^{\mathrm{b}} \\
3.28 & \pm 0.12^{\mathrm{a}} \\
9.45 & \pm 0.36^{\mathrm{a}} \\
13.11 & \pm 0.27^{\mathrm{b}} \\
14.44 & \pm 0.26^{\mathrm{b}} \\
0.176 & \pm 0.011^{\mathrm{c}}\end{aligned}$ & $\begin{aligned} & 94.62 \pm 0.34^{\mathrm{a}} \\
&-0.24 \pm 0.11^{\mathrm{a}} \\
& 12.70 \pm 0.61^{\mathrm{ab}} \\
& 3.30 \pm 0.52^{\mathrm{a}} \\
& 10.42 \pm 1.30^{\mathrm{a}} \\
& 12.70 \pm 0.61^{\mathrm{ab}} \\
& 13.89 \pm 0.82^{\mathrm{ab}} \\
& 0.120 \pm 0.006^{\mathrm{a}} \\
& \text { utlet temperatu }\end{aligned}$ & $\begin{aligned} 94.72 & \pm 0.52^{\mathrm{a}} \\
-0.13 & \pm 0.19^{\mathrm{a}} \\
12.10 & \pm 0.17^{\mathrm{a}} \\
3.53 & \pm 0.35^{\mathrm{a}} \\
10.29 & \pm 0.24^{\mathrm{a}} \\
12.10 & \pm 0.61^{\mathrm{a}} \\
13.25 & \pm 0.29^{\mathrm{a}} \\
0.141 & \pm 0.001^{\mathrm{b}}\end{aligned}$ \\
\hline Nonenzymatic browning (OD/g of DM) & $60^{\circ} \mathrm{C}$ & $80^{\circ} \mathrm{C}$ & $100^{\circ} \mathrm{C}$ \\
\hline $\begin{array}{l}L \\
a \\
b \\
\Delta E: \text { slurry } \\
\Delta E: \text { cheese } \\
\text { Chroma } \\
\text { Browning index } \\
\text { Nonenzymatic browning (OD/g of DM) }\end{array}$ & $\begin{aligned} 95.05 & \pm 0.47^{\mathrm{b}} \\
0.09 & \pm 0.00^{\mathrm{b}} \\
10.22 & \pm 0.37^{\mathrm{a}} \\
5.66 & \pm 0.63^{\mathrm{b}} \\
13.27 & \pm 1.21^{\mathrm{c}} \\
10.22 & \pm 0.37^{\mathrm{a}} \\
11.18 & \pm 0.48^{\mathrm{a}} \\
0.142 & \pm 0.013^{\mathrm{a}}\end{aligned}$ & $\begin{aligned} 94.62 & \pm 0.34^{\mathrm{b}} \\
-0.24 & \pm 0.11^{\mathrm{a}} \\
12.70 & \pm 0.61^{\mathrm{b}} \\
3.30 & \pm 0.52^{\mathrm{a}} \\
10.42 & \pm 1.30^{\mathrm{b}} \\
12.70 & \pm 0.61^{\mathrm{b}} \\
13.89 & \pm 0.82^{\mathrm{b}} \\
0.120 & \pm 0.006^{\mathrm{a}}\end{aligned}$ & $\begin{aligned} 84.32 & \pm 0.67^{\mathrm{a}} \\
3.93 & \pm 0.23^{\mathrm{c}} \\
19.53 & \pm 1.27^{\mathrm{c}} \\
9.85 & \pm 0.98^{\mathrm{c}} \\
2.18 & \pm 0.66^{\mathrm{a}} \\
19.92 & \pm 1.26^{\mathrm{c}} \\
29.28 & \pm 2.22^{\mathrm{c}} \\
0.343 & \pm 0.022^{\mathrm{b}}\end{aligned}$ \\
\hline
\end{tabular}

of white cheese powder. Conflicting experimental results are reported for the effect of inlet air temperature on free fat content (Vignolles et al., 2007). Park et al. (2014) reported that spray drying of whey protein concentrate at an inlet air temperature of $200^{\circ} \mathrm{C}$ increased the surface free fat content relative to that at $220^{\circ} \mathrm{C}$ but not $180^{\circ} \mathrm{C}$. In contrast, in the current study, an increase in inlet air temperature caused an increase in free fat content. The formation of capillaries and vacuoles, which make fat more susceptible to spray-drying conditions, increases with high inlet air temperatures, resulting in greater free fat content (Farkye, 2006).

Atomization during spray drying had a similar physical effect as homogenization. As the emulsifying degree of fat increases with homogenization, free fat content decreases (Kelly et al., 2002, 2009b; Vignolles et al., 2007). Free fat content is inversely related to particle size, and increasing atomization pressure causes a decline in the particle size (Farkye, 2006). Scanning electron micrographs of white cheese powders produced at different atomization pressures showed that high atomization pressure resulted in larger numbers of small particles in the powder (Figure 1a, b, and c). Wrinkled particles of different sizes were observed. Particle size is an important factor in surface free fat of dairy powders. A reduction in particle size represents an increase in surface area per unit mass, resulting in more particle surface being covered by free fat (Park and Drake, 2014). In contrast, in this study, high atomization pressure $(588 \mathrm{kPa})$ resulted in lower free fat content than did lower atomization pressures (294 and $441 \mathrm{kPa}$ ), which may be related to shape and surface structure. There is a lack of clear information on the effect of outlet air temperature on free fat content. Kim et al. (2009b) reported a positive correlation between free fat content and outlet air temperature. However, those authors did not maintain constant inlet air temperatures when increasing outlet air temperatures. In contrast, 
Table 4. Variation of physical properties of white cheese powder with process conditions of spray drying (means $\pm \mathrm{SD})$

\begin{tabular}{|c|c|c|c|}
\hline \multirow[b]{2}{*}{ Item } & \multicolumn{3}{|c|}{ Inlet temperature } \\
\hline & $160^{\circ} \mathrm{C}$ & $195^{\circ} \mathrm{C}$ & $230^{\circ} \mathrm{C}$ \\
\hline $\begin{array}{l}\text { Bulk density }\left(\mathrm{kg} / \mathrm{m}^{3}\right) \\
\text { Tapped density }\left(\mathrm{kg} / \mathrm{m}^{3}\right) \\
\text { Particle density }\left(\mathrm{kg} / \mathrm{m}^{3}\right) \\
\text { Wettability }(\mathrm{s}) \\
\text { Dispersibility }(\%) \\
\text { Solubility index }(\%) \\
\text { Free fat content }(\%) \\
\text { Water activity }\end{array}$ & $\begin{aligned} 251.0 & \pm 6.8^{\mathrm{b}} \\
473.7 & \pm 2.0^{\mathrm{b}} \\
1036.0 & \pm 5.2^{\mathrm{b}} \\
86.3 & \pm 7.8^{\mathrm{a}} \\
75.37 & \pm 4.05^{\mathrm{a}} \\
72.67 & \pm 0.42^{\mathrm{a}} \\
39.71 & \pm 0.45^{\mathrm{a}} \\
0.138 & \pm 0.021^{\mathrm{a}}\end{aligned}$ & $\begin{aligned} & 235.2 \pm 3.6^{\mathrm{a}} \\
& 469.8 \pm 5.4^{\mathrm{b}} \\
& 1046.3 \pm 22.0^{\mathrm{b}} \\
& 121.4 \pm 14.9^{\mathrm{b}} \\
& 73.13 \pm 2.13^{\mathrm{a}} \\
& 75.95 \pm 1.16^{\mathrm{b}} \\
& 40.89 \pm 0.45^{\mathrm{b}} \\
& 0.236 \pm 0.020^{\mathrm{c}} \\
& \text { ttomization pressı }\end{aligned}$ & $\begin{array}{l}238.1 \pm 4.0^{\mathrm{a}} \\
456.5 \pm 5.6^{\mathrm{a}} \\
975.2 \pm 17.3^{\mathrm{a}} \\
138.8 \pm 26.6^{\mathrm{b}} \\
76.46 \pm 1.24^{\mathrm{a}} \\
76.81 \pm 0.96^{\mathrm{b}} \\
40.78 \pm 0.99^{\mathrm{b}} \\
0.179 \pm 0.026^{\mathrm{b}}\end{array}$ \\
\hline Water activity & $294 \mathrm{kPa}$ & $441 \mathrm{kPa}$ & $588 \mathrm{kPa}$ \\
\hline $\begin{array}{l}\text { Bulk density }\left(\mathrm{kg} / \mathrm{m}^{3}\right) \\
\text { Tapped density }\left(\mathrm{kg} / \mathrm{m}^{3}\right) \\
\text { Particle density }\left(\mathrm{kg} / \mathrm{m}^{3}\right) \\
\text { Wettability }(\mathrm{s}) \\
\text { Dispersibility }(\%) \\
\text { Solubility index }(\%) \\
\text { Free fat content }(\%) \\
\text { Water activity }\end{array}$ & $\begin{aligned} 247.1 & \pm 3.6^{\mathrm{b}} \\
472.9 & \pm 5.3^{\mathrm{a}} \\
1044.4 & \pm 6.9^{\mathrm{a}} \\
59.2 & \pm 17.5^{\mathrm{a}} \\
75.64 & \pm 0.68^{\mathrm{b}} \\
77.13 & \pm 1.72^{\mathrm{b}} \\
40.86 & \pm 0.79^{\mathrm{b}} \\
0.124 & \pm 0.016^{\mathrm{a}}\end{aligned}$ & $\begin{aligned} & 235.2 \pm 3.6^{\mathrm{a}} \\
& 469.8 \pm 5.4^{\mathrm{a}} \\
& 1046.3 \pm 22.0^{\mathrm{a}} \\
& 121.4 \pm 14.9^{\mathrm{b}} \\
& 73.13 \pm 2.13^{\mathrm{b}} \\
& 75.95 \pm 1.16^{\mathrm{ab}} \\
& 40.89 \pm 0.45^{\mathrm{b}} \\
& 0.236 \pm 0.020^{\mathrm{b}} \\
& \text { Outlet temperatu }\end{aligned}$ & $\begin{aligned} 250.9 & \pm 5.8^{\mathrm{b}} \\
495.3 & \pm 6.4^{\mathrm{b}} \\
1031.7 & \pm 5.9^{\mathrm{a}} \\
83.2 & \pm 10.0^{\mathrm{a}} \\
69.55 & \pm 0.98^{\mathrm{a}} \\
74.88 & \pm 0.39^{\mathrm{a}} \\
38.84 & \pm 0.41^{\mathrm{a}} \\
0.210 & \pm 0.020^{\mathrm{b}}\end{aligned}$ \\
\hline & $60^{\circ} \mathrm{C}$ & $80^{\circ} \mathrm{C}$ & $100^{\circ} \mathrm{C}$ \\
\hline $\begin{array}{l}\text { Bulk density }\left(\mathrm{kg} / \mathrm{m}^{3}\right) \\
\text { Tapped density }\left(\mathrm{kg} / \mathrm{m}^{3}\right) \\
\text { Particle density }\left(\mathrm{kg} / \mathrm{m}^{3}\right) \\
\text { Wettability }(\mathrm{s}) \\
\text { Dispersibility }(\%) \\
\text { Solubility index }(\%) \\
\text { Free fat content }(\%) \\
\text { Water activity }\end{array}$ & $\begin{aligned} 254.2 & \pm 11.1^{\mathrm{c}} \\
489.6 & \pm 8.4^{\mathrm{c}} \\
1079.3 & \pm 18.5^{\mathrm{c}} \\
160.3 & \pm 25.7^{\mathrm{c}} \\
65.23 & \pm 0.83^{\mathrm{a}} \\
78.03 & \pm 0.62^{\mathrm{b}} \\
41.65 & \pm 0.49^{\mathrm{b}} \\
0.244 & \pm 0.036^{\mathrm{b}}\end{aligned}$ & $\begin{aligned} 235.2 & \pm 3.6^{\mathrm{b}} \\
469.8 & \pm 5.4^{\mathrm{b}} \\
1046.3 & \pm 22.0^{\mathrm{b}} \\
121.4 & \pm 14.9^{\mathrm{b}} \\
73.13 & \pm 2.13^{\mathrm{b}} \\
75.95 & \pm 1.16^{\mathrm{b}} \\
40.89 & \pm 0.45^{\mathrm{b}} \\
0.236 & \pm 0.020^{\mathrm{b}}\end{aligned}$ & $\begin{aligned} 216.0 & \pm 8.8^{\mathrm{a}} \\
407.0 & \pm 5.6^{\mathrm{a}} \\
838.5 & \pm 10.7^{\mathrm{a}} \\
18.9 & \pm 1.9^{\mathrm{a}} \\
86.54 & \pm 0.39^{\mathrm{c}} \\
54.45 & \pm 3.43^{\mathrm{a}} \\
35.16 & \pm 0.16^{\mathrm{a}} \\
0.135 & \pm 0.021^{\mathrm{a}}\end{aligned}$ \\
\hline
\end{tabular}

${ }^{\mathrm{a}-\mathrm{C}}$ Means within a row with different superscripts differ $(P<0.05)$.

Keogh et al. (2004) reported a reduction in free fat at outlet air temperatures up to $100^{\circ} \mathrm{C}$; however, they did not report the formation or variation of free fat because their study was focused on particle size. In this study, a negative correlation was found between free fat content and outlet air temperature (Table 4).

Water activity values measured in white cheese powder samples fluctuated with spray-drying conditions (Table 4). However, all water activity values obtained were $<0.300$, indicating that the powder samples were safe with respect to microbiological growth and chemical reactivity (Roos, 2007; Tapia et al., 2007).

\section{Sensory Evaluation}

The sensory evaluation results are shown in Figure 2. The sensory properties of white cheese powder produced with different inlet air temperatures and atomization pressures were not significant (Figure 2a and $2 \mathrm{~b}$ ); however, outlet air temperature contributed to significant effects on sensory properties (Figure 2c).
Panelists reported increased browning, sensorial caking, and scorched flavor at outlet air temperature of $100^{\circ} \mathrm{C}$. We found no significant differences in cheese flavor with outlet temperatures between $60^{\circ} \mathrm{C}$ and $80^{\circ} \mathrm{C}$ (sensorial scores of $6.53 \pm 0.15$ and $6.99 \pm 0.25$, respectively); however, an outlet air temperature of $100^{\circ} \mathrm{C}$ contributed to lower cheese flavor scores $(5.38 \pm 0.45)$.

\section{CONCLUSIONS}

White cheese powders were produced under different spray-drying conditions, and the effects of spray-drying conditions (inlet air temperature, atomization pressure, and outlet air temperature) on powder quality properties were evaluated. The most important process parameter was outlet air temperature: white cheese powders produced at high outlet air temperatures had increased browning. All white cheese powder samples had a moisture content $<2.85 \%$ and a water activity value of 0.300 ; therefore, they were safe with respect to 
a

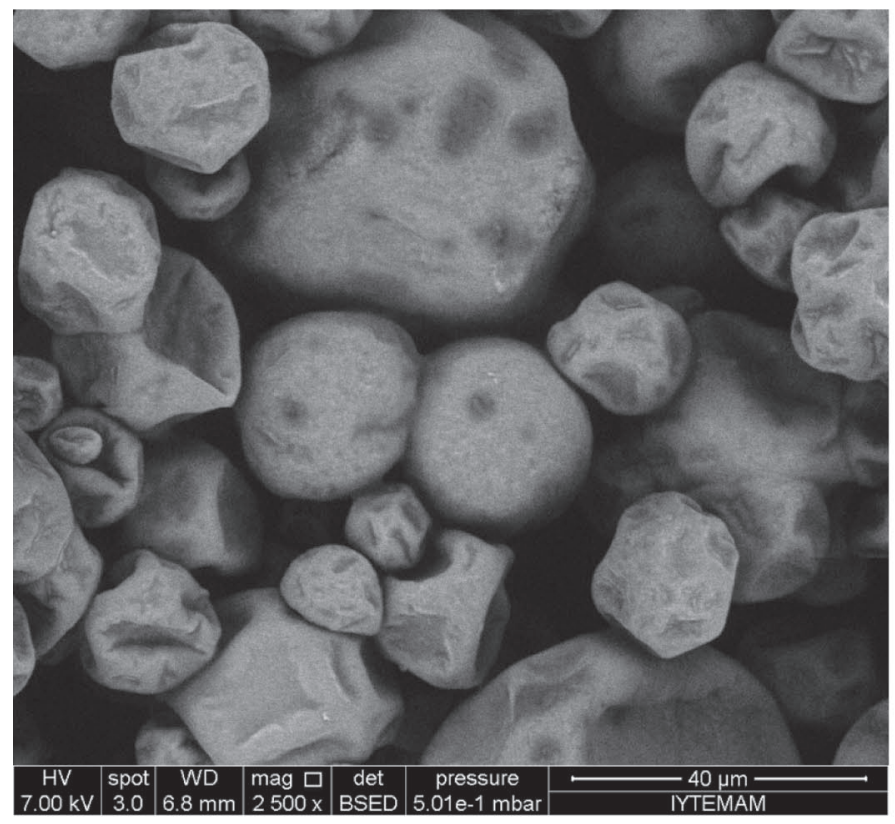

b



c



Figure 1. Scanning electron micrographs of cheese powders produced at different atomization pressures: (a) $294 \mathrm{kPa}$, (b) $441 \mathrm{kPa}$, and (c) $558 \mathrm{kPa}$.

microbiological growth and chemical reactivity. White cheese powder samples with low free fat content had enhanced wettability and dispersibility. Solubility index improved with decreasing temperature. Free fat content was negatively correlated with outlet air temperature and atomization pressure, and positively correlated with inlet air temperature. All white cheese powder samples produced in this study had acceptable sensorial properties except for those produced at an outlet air temperature of $100^{\circ} \mathrm{C}$; these samples had higher scorched flavor and color scores and lower cheese flavor scores. 


\section{a}

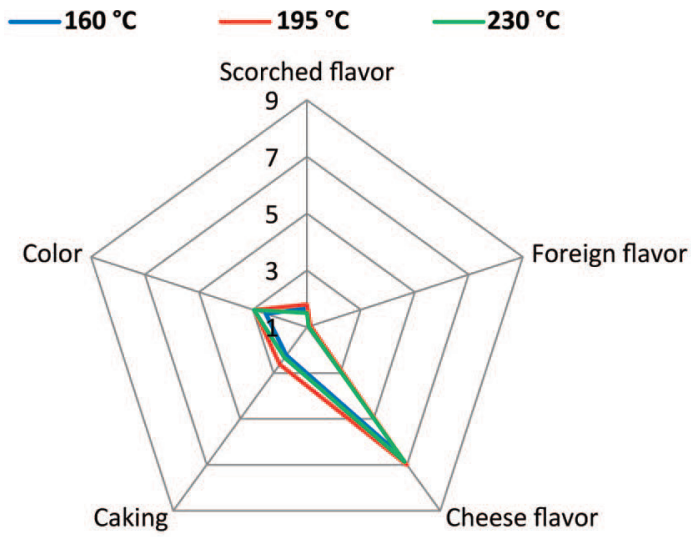

b

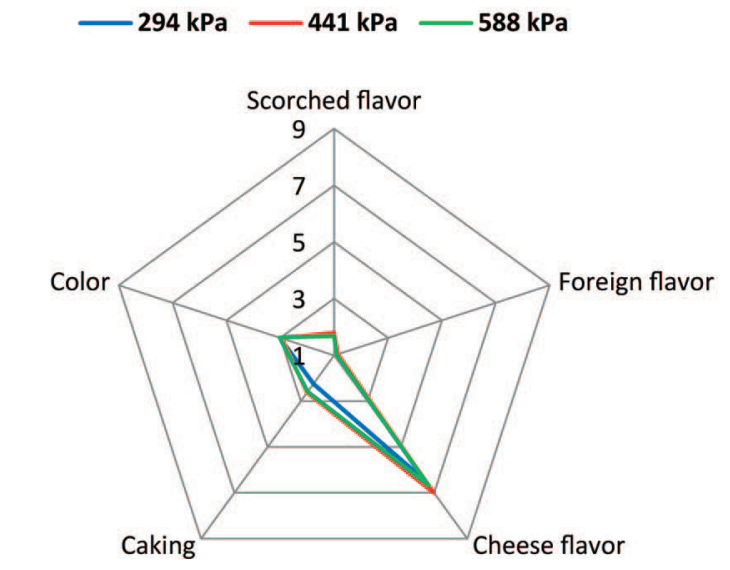

\section{c}

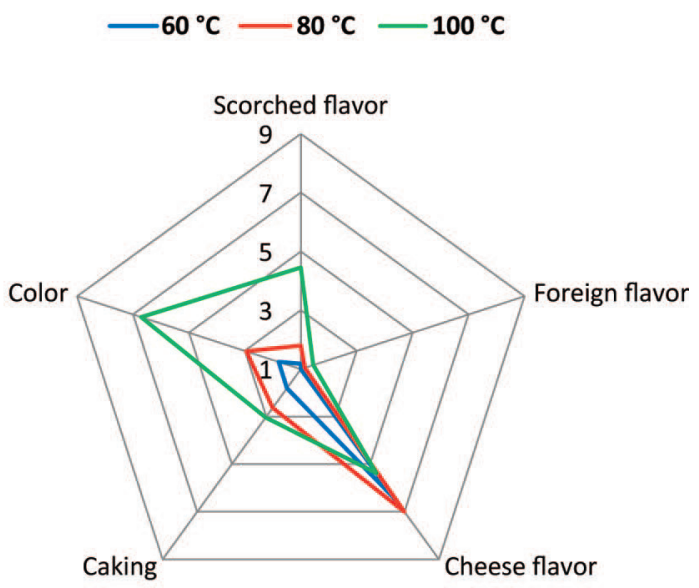

Figure 2. The effects of variation of spray-drying process conditions: (a) inlet air temperature, (b) atomization pressure, and (c) outlet air temperature, on sensory properties of white cheese powder. Color version available online.

\section{ACKNOWLEDGMENTS}

The authors are grateful for the financial support provided for the project no: 1090093 by The Scientific and Technological Research Council of Turkey (TUBITAK, Ankara, Turkey) and for the project no: 2010/ Bil/012 by Ege University Science and Technology Center (EBILTEM, Izmir, Turkey), Sütaş Dairy Company (Istanbul, Turkey) for providing cheese, Yildiz Group (Istanbul, Turkey) for providing the atomizer, and Kipa Chemical Company (Istanbul, Turkey) for providing emulsifying salt.

\section{REFERENCES}

Anandharamakrishnan, C., C. D. Rielly, and A. G. F. Stapley. 2007. Effects of process variables on the denaturation of whey proteins during spray drying. Dry. Technol. 25:799-807.

Anandharamakrishnan, C., C. D. Rielly, and A. G. F. Stapley. 2008. Loss of solubility of $\alpha$-lactalbumin and $\beta$-lactoglobulin during the spray drying of whey proteins. Lebenson. Wiss. Technol. 41:270 277.
AOAC International. 2000. Official Methods of Analysis. 17th ed. AOAC International, Gaithersburg, MD.

Askari, G. R., Z. Emam-Djomeh, and S. M. Mousavi. 2008. Investigation of microwave treatment on the optical properties of apple slices during drying. Dry. Technol. 26:1362-1368.

Barbosa-Canovas, G. V., E. Ortega-Rivas, P. Juliano, and H. Yan. 2005. Food Powders: Physical Properties, Processing, and Functionality. Kluwer Academic Publishers, New York, NY.

Bhandari, B. R., K. C. Patel, and X. D. Chen. 2008. Spray drying of food materials-process and product characteristics. Pages 113-160 in Drying Technologies in Food Processing. X. D. Chen and A. S. Mujumdar, ed. Blackwell Publishing, Oxford, UK.

Cunha, C. R., and W. H. Viotto. 2010. Casein peptization, functional properties, and sensory acceptance of processed cheese spreads made with different emulsifying salts. J. Food Sci. 75:C113-C120.

Erbay, Z., and N. Koca. 2012a. Investigating the effects of operating conditions on the exergetic performance of a pilot-scale spray-drying system. Int. J. Exergy. 11:302-321.

Erbay, Z., and N. Koca. 2012b. Energetic, exergetic and exergoeconomic analyses of spray drying process during white cheese powder production. Dry. Technol. 30:435-444.

Erbay, Z., and N. Koca. 2015. Optimization of spray-drying process in cheese powder production. Food Bioprod. Process. 93:156-165.

Farkye, N. 2006. Significance of milk fat in milk powder. Pages 451462 in Advanced Dairy Chemistry, 3rd ed. Vol. 2 Lipids. P. F. Fox and P. L. H. McSweeney, ed. Springer, New York, NY. 
Filkova, I., L. X. Huang, and A. S. Mujumdar. 2006. Industrial spraydrying systems. Pages 215-254 in Handbook of Industrial Drying. 3rd ed. A. S. Mujumdar, ed. CRC Press, Boca Raton, FL.

Fitzpatrick, J. J., T. Iqbal, C. Delaney, T. Twomey, and M. K. Keogh. 2004. Effect of powder properties and storage conditions on the flowability of milk powders with different fat contents. Int. J. Food Eng. 64:435-444

Fox, P. F. 2011. Cheese: Overview. Pages 534-543 in Encyclopedia of Dairy Sciences. 2nd ed. Vol. 1. J. W. Fuquay, P. F. Fox and P. L. H. McSweeney, ed. Elsevier/Academic Press, London, UK.

Fox, P. F., T. M. Cogan, T. P. Guinee, and P. L. H. McSweeney. 2000. Fundamentals of Cheese Science. Aspen Publications, Gaithersburg, MD

Freudig, B., S. Hogekamp, and H. Schubert. 1999. Dispersion of powders in liquids in a stirred vessel. Chem. Eng. Process. 38:525-532.

Gaiani, C., J. J. Ehrhardt, J. Scher, J. Hardy, D. Desobry, and S. Banon. 2006. Surface composition of dairy powders observed by $\mathrm{X}$-ray photoelectron spectroscopy and effects on their rehydration properties. Colloids Surf. B Biointerfaces 49:71-78.

GEA Niro. 2005a. A/S Niro Atomizer: Determination of wettability. GEA Niro Method No. A5a, Copenhagen. Accessed Jan. 26, 2014. http://www.niro.com/NIRO/CMSDoc.nsf/WebDoc/ndkw6u9bbd.

GEA Niro. 2005b. A/S Niro Atomizer: Determination of surface free fat of powder. GEA Niro Method No. A10a, Copenhagen. Accessed Jan. 26, 2014. http://www.niro.com/NIRO/CMSDoc.nsf/ webdoc/ndkw6u9c45.

Guinee, T. P. 2011. Cheese as a food ingredient. Pages $822-833$ in Encyclopedia of Dairy Sciences. 2nd ed. Vol. 1. J. W. Fuquay, P. F. Fox, and P. L. H. McSweeney, ed. Elsevier/Academic Press, London, UK.

Guinee, T. P., and K. N. Kilcawley. 2004. Cheese: Cheese as an Ingredient. Pages 395-428 in Cheese Chemistry, Physics and Microbiology. 3rd ed. P. F. Fox, P. L. H. McSweeney, T. M. Cogan, and T. P. Guinee, ed. Elsevier/Academic Press, London, UK.

Hardy, J., M. Parmenties, and J. Fanni. 1999. Functionality of nutrients and thermal treatments of food. Proc. Nutr. Soc. 58:579-585.

Hawthorne, J. R. 1944. Methods for determination of solubility of dried whole egg. J. Soc. Chem. Ind. 63:6-8.

Henning, D. R., R. J. Baer, A. N. Hassan, and R. Dave. 2006. Major advances in concentrated and dry milk products, cheese, and milk fat-based spreads. J. Dairy Sci. 89:1179-1188.

IDF. 1981. Milk-Determination of fat content-Gerber butyrometers. IDF Standard 105. International Dairy Federation (IDF), Brussels, Belgium.

IDF. 1982. Determination of the total solid content (cheese and processed cheese). IDF Standard 4A. International Dairy Federation (IDF), Brussels, Belgium.

IDF. 1988. Determination of salt content (Mohr method). IDF Standard 12B. International Dairy Federation (IDF), Brussels, Belgium.

Jinapong, N., M. Suphantharika, and P. Jamnong. 2008. Production of instant soymilk powders by ultrafiltration, spray drying and fluidized bed agglomeration. J. Food Eng. 84:194-205.

Kelly, J., P. M. Kelly, and D. Harrington. 2002. Influence of processing variables on the physicochemical properties of spray dried fatbased milk powders. Dairy Sci. Technol. 82:401-412.

Keogh, K., C. Murray, J. Kelly, and B. O'Kennedy. 2004. Effect of the particle size of spray-dried milk powder on some properties of chocolate. Dairy Sci. Technol. 84:375-384.

Kilic, M., K. Muthukumarappan, and S. Gunasekaran. 1997. Kinetics of nonenzymatic browning in cheddar cheese powder during storage. J. Food Process. Preserv. 21:379-393.

Kim, E. H. J., X. D. Chen, and D. Pearce. 2002. Surface characterization of four industrial spray-dried dairy powders in relation to chemical composition, structure and wetting property. Colloids Surf. B Biointerfaces 26:197-212.

Kim, E. H. J., X. D. Chen, and D. Pearce. 2009a. Surface composition of industrial spray-dried milk powders. 1. Development of surface composition during manufacture. J. Food Eng. 94:163-168.
Kim, E. H. J., X. D. Chen, and D. Pearce. 2009b. Surface composition of industrial spray-dried milk powders. 2. Effects of spray drying conditions on the surface composition. J. Food Eng. 94:169-181.

McClements, D. J. 2005. Food emulsions in practice. Chapter 12 in Food Emulsions: Principles, Practices, and Techniques. 2nd ed. CRC Press, Boca Raton, FL.

Palombo, R., A. Gertler, and I. Saguy. 1984. A simplified method for determination of browning in dairy powders. J. Food Sci. 49:1609-1613.

Park, C. W., E. Bastian, B. Farkas, and M. A. Drake. 2014. The effect of feed solids concentration and inlet temperature on the flavor of spray-dried whey protein concentrate. J. Food Sci. 79:C19-C24.

Park, C. W., and M. A. Drake. 2014. The distribution of fat in dried dairy particles determines flavor release and flavor stability. J. Food Sci. 79:R452-R459.

Paterson, A. H., J. Z. Zuo, J. E. Bronlund, and R. Chatterjee. 2007. Stickiness curves of high fat dairy powders using the particle gun. Int. Dairy J. 17:998-1005.

Richard, B., J. F. Le Page, P. Schuck, C. Andre, R. Jeantet, and G. Delaplace. 2013. Towards a better control of dairy powder rehydration processes. Int. Dairy J. 31:18-28.

Roos, Y. H. 2007. Water activity and glass transition. Pages 29-45 in Water Activity in Foods: Fundamentals and Applications. G. V. Barbosa-Canovas, A. J. Fontana Jr., S. J. Schmidt and T. P. Labuza, ed. Blackwell Publishing, Ames, IA.

Schuck, P. 2002. Spray drying of dairy products: state of art. J. Dairy Sci. $82: 375-382$

Schuck, P. 2011. Milk Powder: Physical and Functional Properties of Milk Powders. Pages 117-124 in Encyclopedia of Dairy Sciences. 2nd ed. Vol. 2. J. W. Fuquay, P. F. Fox and P. L. H. McSweeney, ed. Elsevier, Academic Press, London, UK.

Srinivasan, P., U. S. Annapure, A. K. Sahoo, R. S. Singhal, and P. R. Kulkarni. 2000. Mini-papad containing cheese powder-A novelty snack food. Int. J. Food Sci. Nutr. 51:175-180.

Stapelfeldt, H., B. R. Nielsen, and L. H. Skibsted. 1997. Effect of heat treatment, water activity and storage temperature on the oxidative stability of whole milk powder. Int. Dairy J. 7:331-339.

Svarovsky, L. 1987. Powder Testing Guide: Methods of Measuring the Physical Properties of Bulk Powders. Elsevier Applied Science, New York, NY

Tapia, M. S., S. M. Alzamora, and J. Chirife. 2007. Effects of water activity $\left(\mathrm{a}_{\mathrm{w}}\right)$ on microbial stability: As a hurdle in food preservation. Pages 239-271 in Water Activity in Foods: Fundamentals and Applications. G. V. Barbosa-Canovas, A. J. Fontana Jr., S. J. Schmidt and T. P. Labuza, ed. Blackwell Publishing, Ames, IA.

Thomas, M. E. C., J. Scher, S. Desobry-Banon, and S. Desobry. 2004. Milk powders ageing: Effect on physical and functional properties. Crit. Rev. Food Sci. Nutr. 44:297-322.

Varming, C., L. T. Andersen, M. A. Petersen, and Y. Ardö. 2013. Flavour compounds and sensory characteristics of cheese powders made from matured cheese. Int. Dairy J. 30:19-28.

Varming, C., T. K. Beck, M. A. Petersen, and Y. Ardö. 2010. Volatile compounds and amino acids in cheese powders made from matured cheeses. Pages 435-438 in Expression of Multidisciplinary Flavour Science: Proc. 12th Weurmann Symp., Interlaken, Switzerland. I. Blank, M. Wüst and C. Yeretzian, ed. Institute of Chemical and Biological Chemistry, Zurich University of Applied Sciences, Wadenswil, Switzerland.

Varming, C., T. K. Beck, M. A. Petersen, and Y. Ardö. 2011. Impact of processing steps on the composition of volatile compounds in cheese powders. Int. J. Dairy Technol. 64:197-206.

Vignolles, M. L., R. Jeantet, C. Lopez, and P. Schuck. 2007. Free fat, surface fat and dairy powders: Interactions between process and product-A review. Dairy Sci. Technol. 87:187-236.

Vignolles, M. L., C. Lopez, M. N. Madec, J. J. Ehrhardt, S. Mejean, P. Schuck, and R. Jeantet. 2009. Fat properties during homogenization, spray-drying, and storage affect the physical properties of dairy powders. J. Dairy Sci. 92:58-70. 